RESEARCH ARTICLE

\title{
IMPLEMENTATION OF COUNSELING BY BHABINKAMTIBMAS IN PREVENTING THE SPREAD OF HOAX IN KEBUMEN POLICE STATION
}

\author{
Reyhan Kusuma \\ Central Java Regional Police Department, Indonesia \\ $\triangle$ reyhankusuma50@gmail.com
}

\section{CITED AS}

Kusuma, R. (2020). Implementation of Counseling by Bhabinkamtibmas in Preventing the Spread of Hoax in Kebumen Police Station. Journal of Law and Legal Reform, 1(3), 395-414. DOI: https://doi.org/10.15294/jllr.vli3.36702

\section{ABSTRACT}

Hoax phenomena are becoming more prevalent, especially towards the 2019 Election which makes people uneasy and will cause disruption of security and public order or in Indonesian 'Keamanan dan ketertiban masyarakat (Kamtibmas)'. The National Police as a public servant seeks to maintain the Kamtibmas situation through Bhabinkamtibmas (Bhayangkara pembina keamanan dan ketertiban masyarakat). Bhabinkamtibmas through counseling is very important in preventing the spread of hoaxes. Therefore, research is conducted to find out the description of the spread of hoaxes, the extent to which the implementation of Bhabinkamtibmas counseling is related to the partnership approach and problem solving efforts and the factors that influence counseling in preventing the spread of hoax in order to create a safe and peaceful election in Kebumen Police.

Keyword: Implementation; Counseling; Bhabinkamtibmas; Hoax; General Election 


\section{TABLE OF CONTENTS}

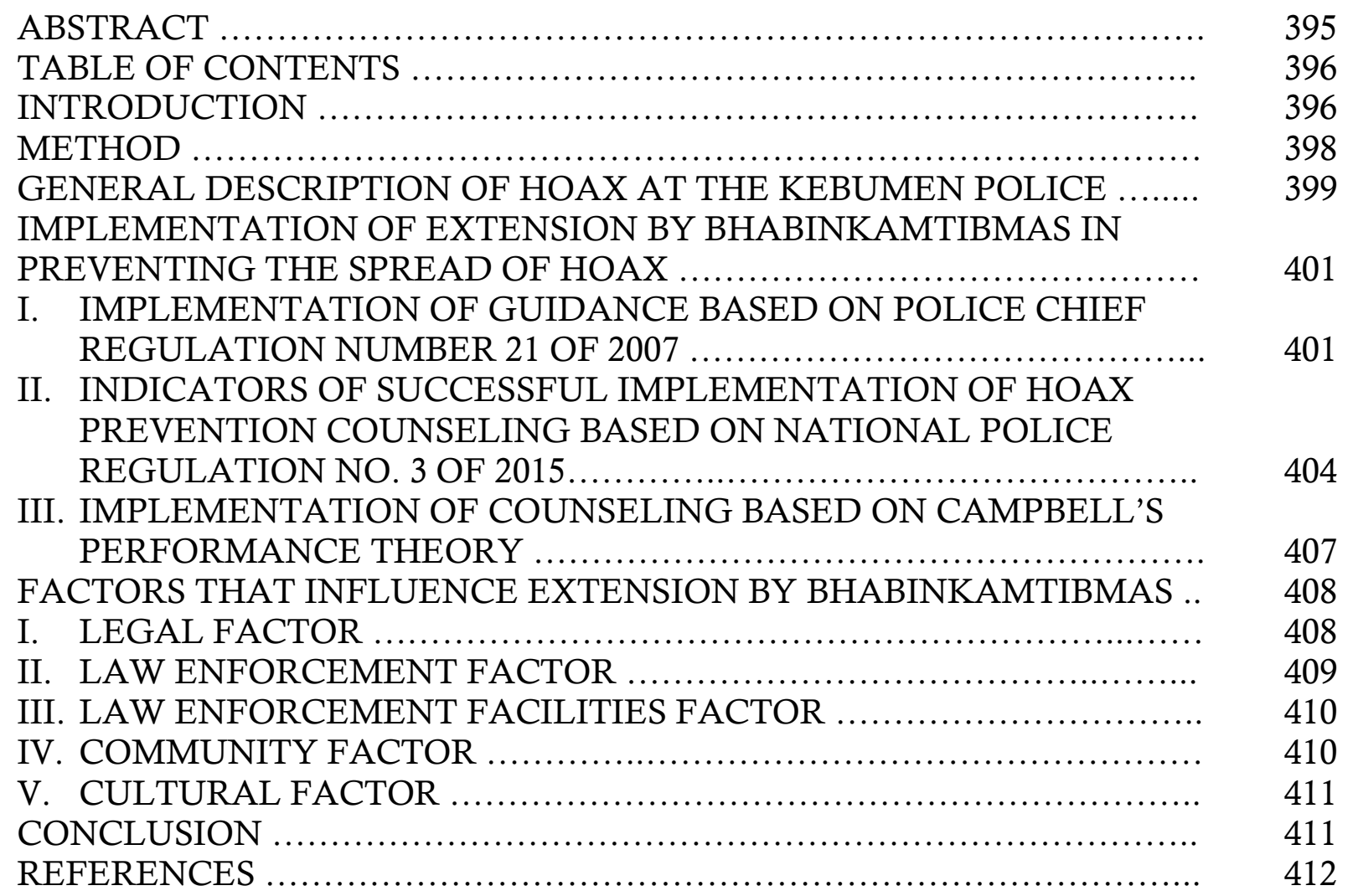

\section{INTRODUCTION}

The rapid flow of information technology and the influence of globalization makes it easy for people to obtain various information. One of them is through social media. This can be explained in the Graphic Information on Internet User Behavior in Indonesia at the Indonesian Internet Service Providers Association (APJII) in 2017 found that the penetration of internet users from 262 million total population of Indonesia is 142.26 million. Java Island became the island that dominates Internet users in Indonesia with 58.08 percent. This shows that the people in Java are active in using the Internet in their daily lives. Obtained $87.13 \%$ using the internet to access social media so it can be concluded that $87.13 \%$ actively uses social media.

According to Taprial and Kanwar (2012) in Rahadi (2017: 58), "social media is the media used by individuals to become social, online by sharing content, news, photos and others with others." From this definition it is clear, that the public can share information and vice versa with the government. Then "Digital social networks have substantially facilitated the process of information sharing and knowledge construction" (Hara \& Sanfilippo, 2016; Park, 2017). But one negative impact of social media is the spread of hoaxes. However, "this information system also come with 
problems, one of which involves the spread of inaccurate information or fake news" (Tambuscio, Ruffo, Flammini, \& Menczer, 2015). Misinformation is more quickly disseminated through social media when there is high uncertainty and high demand for public information about the issues such as crisis (Spence, Lachlan, Edwards, \& Edwards, 2016) and health concerns (Jang, McKeever, Mckeever, \& Kim, in Press).

In the survey of the Indonesian Telematics Society (Mastel) in 2017 it was explained that the form of hoax spreading channels was still dominated through social media at 94.2\%. According to Rahadi (2017: 61), "Hoax is an attempt to deceive or outsmart the reader / listener to believe something, even though the creator of the fake news knows that the news is fake." Hoax triggers public unrest and causes hate crime such as persecution in reporting on news tribunnews.com entitled "Because the News of a Young Man's Hoax in Brebes is Engaged by the Mass"

The phenomenon of hoax is a social problem that causes public unrest so that it disturbs the maintenance of public security and order or 'pemeliharaan keamanan dan ketertiban masyarakat' (Harkamtibmas). as we know that in 2019 there will be simultaneous elections for the first time in the history of Indonesia. Simultaneous elections will be held on April 17, 2019. According to Mauludi (2018: 260) that "Fake news tends to be more interesting, the most common material is fake political news." And According to Gilligan and Gologorsky (2019) that "From politics to daily news stories to scientific, concern for public news and media misinformation is growing. This type of 'fake news' as it is often called, is created to influence public onion or for political motives". Then Based on media coverage in online media titled "Hoax is predicted to increase ahead of the election. , The officers were asked firmly. And recently there was an appalling hoax related to the holding of 2019 simultaneous elections, reported news.detik.com with the title "Hoax 7 Containers of Voting Ballots". As stated by the Chairperson of the General Election Commission (KPU) of Central Java Province Sudrajat (2019), "Hoax will damage the credibility and integrity of the holding of elections and cause social conflict" and then based on Parkinson (2016) and Read (2016) that "Incorrect information played a critical role in the eventual outcome of the election".

The main activity that must be carried out by members of the Indonesian National Police is to build resilience and deterrence of citizens against crime. This is in line with Polri's efforts in carrying out preventative actions from various aspects that have the potential to interfere with Kamtibmas (crime prevention). Crime prevention efforts can be effective actions carried out by members of Polri in the field, especially members whose task area is directly in contact with the community, such as Bhabinkamtibmas (Humberto, 2010: 50 in Wowor, 2016: 2). One of the functions of Bhabinkamtibmas Article 26 Number (1) point b of Police Chief Regulation Number 3 of 2015 is "to guide and educate in the field of law and Kamtibmas to increase legal awareness and Kamtibmas by upholding Human Rights (HAM)". Counseling conducted has an important role to increase public awareness so that the media is wise so that it is not easy to spread hoaxes.

The rise of the Hoax phenomenon in the Kebumen Police jurisdiction shows that public awareness is still low to prevent the spread of hoaxes. There are cases of hoaxes through social media that could seize Kebumen's public attention as 
kamtibmas disruption throughout 2018, namely, (1) Occurring in August 2018, namely the Hoax case which unsettled Kebumen residents with the emergence of Broadcast in the short message application about the existence of DPO cases of Mabel Polri terrorism, (2) Occurred in October 2018, the Hoax case of an 8.2 magnitude earthquake (SR) earthquake and the impact of the tsunami would hit the waters of Kebumen, making the people of Kebumen worried and uneasy. Hoax is a social problem that is difficult to get rid of because the behavior of hoaxes is spread by the community itself, so one of the pre-emptive efforts undertaken by the Police is to conduct counseling to increase public awareness in preventing the spread of hoaxes.

\section{METHOD}

Previous research on preventing the spread of hoaxes has been carried out by Annas $Z$ (2018). WhatsApp social media management as a means of extension is not optimal because there are still shortages at each stage of the activity. Likewise, with hoax prevention counseling methods there is a lack of knowledge about hoaxes, communication skills, and multimedia skills at Bhabinkamtibmas and the lack of WhatsApp group socialization.

Subsequent research conducted by Aditya R. N. (2018) suggests the role of Bhabinkamtibmas in preventing religious-based social conflict is considered to be able to carry out its duties and roles in establishing partnerships with warring parties so that the situation of the Bogor City Police Resort area is quite conducive.

The approach used in this research is a qualitative method that aims to explain the phenomenon profusely through data collection. A qualitative approach is a particular tradition in social science that is fundamentally dependent on observing humans, both in their area and in their terminology. Qualitative research also produces detailed information explained by Moleong (2014: 76) "A qualitative approach produces detailed information about a particular case or situation that can and may occur even though this approach is less generalizable as a quantitative approach". This type of research used to obtain in-depth and comprehensive research results is descriptive analysis. According to Nazir in Prastowo, (2011: 201), "Descriptive method is a method used to examine the status of a group of people, an object, a set of conditions, a system of thought, or a class of events in the present". In order to obtain complete information related to the implementation of Bhabinkamtibmas counseling in the prevention of the spread of hoaxes.

In addition, this study identifies the stages of Bhabinkamtibmas counseling based on Police Chief Regulation number 3 of 2015 concerning community policing (Polmas) including the planning phase, the implementation phase, and the control phase. As well as indicators of the success of counseling by Bhabinkamtibmas in Police Chief Regulation number 21 of 2007 concerning Guidance and counseling or 'Bimbingan dan Penyuluhan (Binluh)', covering four aspects, namely aspects of the performance of the implementation of Community Policing, aspects of Polmas and Bhabinkamtibmas development, aspects of society, and aspects of Polri and community relations. 
Then this study developed the concept of media literacy Weni (2003) in Iriantara (2017: 68): accessing mass media messages, analyzing mass media messages, evaluating mass media messages, and producing mass media messages. As well as in this study developing Campbell's performance theory in analyzing the implementation of counseling by Bhabinkamtibmas, there are 8 components of Campbell's performance namely Job specific task proficiency, Non-job specific task proficiency, Written-oral communication task, Demonstrating effort, Maintaining personal discipline, Facilitating peer peer and team performance, Supervision, and Management administration. Furthermore, this study develops law enforcement theory (Soekanto: 2014), there are 5 factors in law enforcement, namely the legal factors themselves, law enforcement factors, facility or facility factors, community factors, and cultural factors, this theory is used in identifying the factors that influence counseling by Bhabinkamtibmas.

\section{GENERAL DESCRIPTION OF HOAX AT THE KEBUMEN POLICE}

The following will describe the description of the spread of Hoax in the Law Area of Kebumen Police Station in the 2017 to 2019 (Until February). above there are 3 cases of hoaxes since 2017 until 2019 (February) which occurred in the Kebumen District Police Station. Of the three hoax cases, none of the suspected hoaxes were investigated by the Kebumen Police, so no hoax cases were charged by the Kebumen Police. This is because although the three news hoaxes can be snared by the law because it upsets the Kebumen people but there are no Kebumen people who report the hoax news.

The three cases of hoaxes are spread through social media and short message applications. The first hoax case regarding the emergence of the Police DPO Broadcast about Terrorism cases. In the Broadcast, women on behalf of Sri Pujianti (36), residents of Bejiruyung Village, Sempor Tengah District, Kebumen Regency, were sought by the Elite Detachment 88 Special Detachment or Detachment 88 elite. This news developed and unsettled the community, then Kebumen police clarified that the news was a hoax. Because there was no Kebumen community who reported the broadcast of the DPO broadcast, Kebumen Police through the Cyber Patrol Subsatgas did not further investigate who broadcasted the broadcast. But it is estimated that there is another charge from the hoax news, which is estimated that the hoax news is only a strategy made by the Victims of Fraud Sri Pujianti so that the woman came out of her hiding place which has been missing since the end of 2017.

The second case of hoaxes is the emergence of a chain chat message that says a Tsunami is coming. In the message mentioned that the districts of Tegal, Brebes, Kebumen and Purworejo there will be a shift of fault Lasem fault which is expected to cause an earthquake with a magnitude of $8.2 \mathrm{SR}$. The message said that the earthquake will occur on December 18, 2018. From the earthquake Kebumen, Cilacap and Purworejo Regencies will be affected by the Tsunami. This news is very 
disturbing to the public. However, just like the previous hoax case because no one reported the case was not further investigated.

The third hoax case is the spread of chain videos through the Whatsapp Chat application about fish flooding in the middle of the highway. In the video seen the residents who picked fish. Next to the video there is a blue inscription "Kebumen latitude Wadas Reservoir". This video disturbs the public because it is feared that the cause of the fish flood is the Wadaslintang Reservoir Kebumen broken and overflowed.

According to the Smart Book of Bhabinkamtibmas (2016) there are several factors causing Hoax in the community:

a. Social media is anonymous, so it provides a sense of security for people who intend to evil and like throwing a hoax.

Social media is online media that support social interaction by using webbased technology that turns communication into interactive dialogue so that interaction is possible without meeting and face-to-face. Social media users can register unlimited accounts to make a lot of fake accounts found (accounts that are used not for the right reasons for example to see the target account and to spread hoaxes). Data from the National Police Headquarters of Cybercrime Unit of 500 million fake Facebook accounts spread in Indonesia in 2017. Fake accounts are anonymous (making no identity) so that makes some people who want to abuse the account to do evil.

b. The still very low level of public literacy on online media or social media so that they do not think long about the impact caused by these uses.

The ability of media literacy is the ability of individuals to study the media critically, reflectively, and independently and has the responsibility of utilizing the media (Iriantara, 2017: 68). Media literacy is related to the literacy ability of the media according to Sumadiria (2014: 264) "... Media literacy is directed at building a joint cultural and intellectual awareness movement about the importance of responding to media flows." So that the public will be critical in responding to any news through the media that circulates. Literacy media is one of the most prominent corrective efforts, according to Lazer et al.(2017) that "In the currenct context of fake news, one of the most prominent corrective effrots is to call for media literacy interventions." With good media literacy skills, public awareness and participation will increase so that the spread of hoaxes can be prevented. To find out the level of media literacy in Kebumen community, media literacy competencies will be used according to Weno (2003) in Iriantara (2017: 68).

The spread of hoaxes in the Kebumen District Police Station in 2017 s.d. 2019 (February) there have been 3 cases of hoaxes, namely Terrorist DPO broadcasts, the threat of an earthquake of 8.2 magnitude and tsunami and the distribution of fish flood videos in Wadas Lintang Kebumen Reservoir. The background of the spread of hoaxes in the Kebumen Polres area is due to the consumptive culture of the community where almost all of the Kebumen people already have an android mobile phone that is not supported by good media literacy skills in using the Internet. 
1. Access mass media messages

2. Analyzing mass media messages

3. Evaluating mass media messages

4. Producing mass media messages.

c. c. Indonesian culture in general is still oriented towards "jarene" or people say, and does not have the tradition of confirming.

d. The community is still fun with new things, including the use of social media without taking into account the possibility that will happen.

e. Lack of productive work

Low media literacy is related to the education level of Kebumen people, which is still relatively low, only a few Kebumen people have a Bachelor's education. This is also related to the type of livelihood of the Kebumen people who are generally a farmer, so this makes the Kebumen people easily believe in hoax news.

\section{IMPLEMENTATION OF EXTENSION BY BHABINKAMTIBMAS IN PREVENTING THE SPREAD OF HOAX}

\section{IMPLEMENTATION OF GUIDANCE BASED ON POLICE CHIEF REGULATION NUMBER 21 OF 2007}

Stages of management about counseling are more specifically explained in the Regulation of the National Police Chief No. 21 of 2007 concerning Guidance and Socialization (Bimbingan dan Penyuluhan hereinafter called as Binluh). In articles 8, 9, 10, and 11 these regulations describe a series of activities from the planning stage to the control. Guidance for preparation in the implementation of Binluh is regulated in Article 8. While the implementation stage is regulated in Articles 9 and 10. The control phase (in the Decree of the Minister mentioned Analysis and Evaluation) is explained in Article 1l. In order to be able to analyze the Kamtibmas message regarding prevention of the spread of hoaxes, the following stages are in accordance with the Decree number 21 of 2007 concerning Binluh.

\section{A. Planning}

In Article 8 Police Chief Regulation number 21 of 2007 concerning Binluh regulates the preparation stage which includes several factors as follows:

The first factor, in general, the material delivered by Bhabinkamtibmas can be in the form of text messages, pictures or videos. Bhabinkamtibmas must understand about the material to be delivered, so that Bhabinkamtibmas before taking a picture or 
video from the internet is expected to have media literacy capabilities, namely at the level of analyzing the material well, this is intended so that Bhabinkamtibmas is not wrong in delivering material preventing the spread of hoaxes. For the production of messages in the form of images and videos cannot be done optimally by the Kebumen Police Bhabinkamtibmas because there is a need for skills to make messages in the form of images and videos. The Kebumen Police Bhabinkamtibmas utilize the Kebumen Police official site in the form of Instagram, Facebook, Twitter and also official sites such as the Police Public Relations Div on Instagram to take messages in the form of pictures and videos. In March 2018 there was an anti hoax declaration made by Kebumen Police. Submission of anti-hoax in the form of anti-hoax declaration video so that it was followed by all people in Kebumen. This was used by Bhabinkamtibmas as a momentum to convey anti-hoax messages to the residents of the fostered villages.

The second factor, coordination with officials can be interpreted by every extension activity carried out in the knowledge of local officials or with local officials. Based on research findings that Bhabinkamtibmas still rarely coordinates with local officials so that many activities that should be carried out counseling but Bhabinkamtibmas does not utilize these activities for extension activities to the community.

The third factor, knowledge of hoaxes is related to media literacy, the legal basis of hoaxes and the definition of hoax itself. In general, Bhabinkamtibmas is only limited to knowing that it is not easily provoked by news that is not yet clear. In this case the ability of media literacy and legal knowledge about the spread of hoaxes has not been conveyed only in the form of appeals to the dangers of hoaxes.

The fourth factor, in arranging the activity organizing team, the Kebumen Police Bhabinkamtibmas has not implemented one Bhabinkamtibmas program in one village. This is due to the lack of Kebumen Police personnel and there are still Bhabinkamtibmas who have a place to live far from their fostered village without an official residence provided.

The fifth factor, delivery of anti-hoax counseling can use the Whatsapp (WA) short message application. All Bhabinkamtibmas have WA because they are used in fast reporting of every activity that has been carried out.

Based on the explanation of planning in accordance with Article 8 Perkap number 21 of 2007 concerning Binluh, it was carried out quite well but there were still shortcomings such as coordination with surrounding officials, readiness of officers who understood hoax material and placement of 1 Bhabinkamtibmas 1 village which was still lacking.

\section{B. Practice}

Article 9 Perkap 21 of 2007 concerning Binluh explains at the stage of implementation that must be carried out by Bhabinkamtibmas officers, namely:

The first factor, the factor of introducing yourself has been fulfilled because based on the results of observations to the Kebumen Police Department Bhabinkamtibmas 
when attending activities in the village and conducting counseling always introduce themselves.

The second factor, based on the results of an interview with Bhabinkamtibmas Sruweng Sector Police that in conducting counseling to prevent the spread of hoaxes, Bhabinkamtibmas was not equipped with sufficient knowledge about the applicable legal rules that can ensnare the perpetrators of hoax spreaders.

The third factor, in delivering hoax prevention counseling, sometimes Bhabinkamtibmas conveys a message in Javanese, namely everyday language used in Central Java, especially in the Kebumen region and sometimes interspersed with humor.

The fourth factor, as technology develops so that conditions in the era of technological sophistication make communication facilities also develop, one of which is internet technology. The majority of Kebumen people have been able to use the internet but are not equipped with good media understanding skills. It will be easily affected by hoaxes because most hoaxes circulate through the internet.

The fifth factor, props used when conducting counseling through WA are WA and android mobile. Whereas to conduct counseling directly can use a projector or made Kamtibmas messages in the form of images or videos, so that the public can better understand than just in the form of talks.

The sixth factor, the mastery of the audience is one of the capabilities that must be possessed by officers providing counseling to the community. Based on observations to the Bhabinkamtibmas Kebumen Police Station, that the ability to master the audience is still lacking, the indicators are from the material delivered by Bhabinkamtibmas, only a few responses from the community responded to messages from Bhabinkamtibmas. This is because the Bhabinkamtibmas flight hours are not many because of the busyness that Bhabinkamtibmas has in Kebumen Police Station and the minimum number of members of Bhabinkamtibmas Kebumen who have followed Dikjur.

The Seventh factor, in carrying out counseling the time required is quite long and based on observations there are complaints from the community against members of Bhabinkamtibmas who like not being on time with the education schedule that has been made. Bhabinkamtibmas does not often do this counseling because Bhabinkamtibmas is busy with concurrent work.

The eighth factor, in the implementation of counseling, Bhabinkamtibmas always takes the time to provide an opportunity for the audience to give questions. Although in its implementation only a few people responded according to the observations made in Kalirejo Village.

Obtained based on the above that in the implementation factor can be done quite well, but there are still obstacles in terms of mastery of the material, the mastery of the audience and the efficient use of time. 


\section{Control}

Analysis and evaluation of guidance and counseling activities carried out through four stages, the first stage is the monitoring phase, starting from the activity, during the process and after the activity with the goal objectives are achieved. Every Bhabinkamtibmas activity is supervised by the National Police Chief and the Community Binit Work Unit. If the Kapolsek and Kanmas Binmas do not have an activity, they can directly monitor the activities of Bhabinkamtibmas by participating in the activity.

The second stage is the recording stage, the recording stage has been done well. The recording phase is carried out by the Community Service Unit by collecting all the activities that have been carried out by Bhabinkamtibmas. Recording activities also function as accountability reports. The third step in controlling is evaluating the implementation of the Bhabinkamtibmas report. If Bhabinkamtibmas which is required to carry out eating activities will be given a reward by Kasat Binmas. The following statement Kasat Binmas.

The fourth step, the end of the series of analysis and evaluation activities is reporting. Reporting the results of analysis and evaluation by Kasat Binmas to the leadership is given in the form of Sat Binmas monthly financial accountability reports obtained from each police station report to Kebumen Police. Bhabinkamtibmas report is made by Bhabinkamtibmas itself in accordance with the activities carried out by adjusting the previous activity plan. Bhabinkamtibmas reports are reported every month to the Binmas Community Office and will be forwarded to the Binmas Community Headquarters as a matter of accountability to the leadership.

\section{INDICATORS OF SUCCESSFUL IMPLEMENTATION OF HOAX PREVENTION COUNSELING BASED ON NATIONAL POLICE REGULATION NO. 3 OF 2015}

To measure the results of implementing hoax prevention counseling, articles 19, 20, 21, 22 of Perkap number 3 of 2015 on Community Policing (Pemolisian Masyarakat) are used as guidelines for analysis, as follows:

a. Indicators of success of Community Policing, seen from the aspect of the performance of Community Policing

b. Indicators of success of community policing, seen from the aspects of Polmas and Bhabinkamtibmas

c. Indicators of success are seen from the aspect of society

d. The indicator of the success of the Community Policing is seen from the aspect of the relationship between the Police and the Community 
Table 1. Indicators of Community Policing Success Based on Perkap Number 3 of 2015

\begin{tabular}{|c|c|c|c|}
\hline No & Article & Indicator & Fulfilled \\
\hline 1 & 2 & 3 & 4 \\
\hline 1 & 19 & $\begin{array}{l}\text { Increased intensity of communication between the } \\
\text { Community Policemen with } \\
\text { Bhabinkamtibmas and the community; }\end{array}$ & $\checkmark$ \\
\hline 2 & 19 & $\begin{array}{l}\text { increased relationship intimacy } \\
\text { Polmas bearer with Bhabinkamtibmas with the } \\
\text { community; }\end{array}$ & - \\
\hline 3 & 19 & increasing public trust in the National Police; & 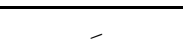 \\
\hline 4 & 19 & $\begin{array}{l}\text { the increasing intensity of communication forum } \\
\text { activities between the National Police and the } \\
\text { community; }\end{array}$ & $\checkmark$ \\
\hline 5 & 19 & $\begin{array}{l}\text { increased sensitivity / awareness of the community } \\
\text { towards Kamtibmas problems in their environment; }\end{array}$ & $\checkmark$ \\
\hline 6 & 19 & $\begin{array}{l}\text { increased information / advice from the public about } \\
\text { the National Police } \\
\text { accountability for the implementation of Polri's } \\
\text { duties; }\end{array}$ & $\checkmark$ \\
\hline 7 & 19 & increased public obedience to the law; & $\checkmark$ \\
\hline 8 & 19 & $\begin{array}{l}\text { increased public participation in providing } \\
\text { Kamtibmas information, early warning and events; }\end{array}$ & $\checkmark$ \\
\hline 9 & 19 & $\begin{array}{l}\text { increasing the ability of the community to eliminate } \\
\text { the root of the problem; }\end{array}$ & - \\
\hline 10 & 19 & $\begin{array}{l}\text { increasing the existence and functioning of problem } \\
\text { solving mechanisms by the police and the } \\
\text { community; }\end{array}$ & - \\
\hline 11 & 20 & $\begin{array}{l}\text { awareness that the community as stakeholders } \\
\text { must be served; }\end{array}$ & - \\
\hline 12 & 20 & increased sense of duty of duty to the community & $\checkmark$ \\
\hline 13 & 20 & $\begin{array}{l}\text { increasing the spirit of serving and protecting the } \\
\text { community as a professional obligation; }\end{array}$ & $\checkmark$ \\
\hline 14 & 20 & $\begin{array}{l}\text { increased readiness and willingness to accept } \\
\text { complaints / complaints from the public; }\end{array}$ & $\checkmark$ \\
\hline 15 & 20 & $\begin{array}{l}\text { increased speed of responding to complaints / } \\
\text { complaints / public reports; }\end{array}$ & $\checkmark$ \\
\hline 16 & 20 & increased speed approaching the scene; & $\checkmark$ \\
\hline 17 & 20 & $\begin{array}{l}\text { increased readiness to provide assistance that is } \\
\text { needed by the community; }\end{array}$ & $\checkmark$ \\
\hline 18 & 20 & $\begin{array}{l}\text { increased ability to solve problems, conflicts / } \\
\text { disputes between citizens; }\end{array}$ & - \\
\hline
\end{tabular}




\begin{tabular}{|c|c|c|c|}
\hline No & Article & Indicator & Fulfilled \\
\hline 1 & 2 & 3 & 4 \\
\hline 19 & 20 & increased intensity of official visits to residents & $\checkmark$ \\
\hline 20 & 21 & $\begin{array}{l}\text { Polmas and Bhabinkamtibmas members are easily } \\
\text { contacted by the community; }\end{array}$ & $\checkmark$ \\
\hline 21 & 21 & $\begin{array}{l}\text { Complaints / report posts / counters are easy to find } \\
\text { by the public; }\end{array}$ & - \\
\hline 22 & 21 & $\begin{array}{l}\text { the complaint mechanism is easy, fast and } \\
\text { straightforward; }\end{array}$ & $\checkmark$ \\
\hline 23 & 21 & $\begin{array}{l}\text { response / response to complaints } \\
\text { quickly / immediately obtained by the community; }\end{array}$ & - \\
\hline 24 & 21 & increasing public trust in the National Police; & - \\
\hline 25 & 21 & $\begin{array}{l}\text { increasing the ability of FKPM to find, identify the } \\
\text { root of the problem, and solve it; }\end{array}$ & - \\
\hline 26 & 21 & $\begin{array}{l}\text { increasing community independence in overcoming } \\
\text { problems in their environment; }\end{array}$ & - \\
\hline 27 & 21 & $\begin{array}{l}\text { reduced community dependence on the National } \\
\text { Police }\end{array}$ & - \\
\hline 28 & 21 & $\begin{array}{l}\text { increased community support in providing } \\
\text { information and thoughts. }\end{array}$ & $\checkmark$ \\
\hline 29 & 22 & $\begin{array}{l}\text { increased communication intensity } \\
\text { Polmas and Bhabinkamtibmas with the community; }\end{array}$ & $\checkmark$ \\
\hline 30 & 22 & $\begin{array}{l}\text { increasing intensity of FKPM activities at the Police } \\
\text { and Community Partnership Center or other places; }\end{array}$ & - \\
\hline 31 & 22 & $\begin{array}{l}\text { the increasing intensity of cooperative activities } \\
\text { between Community Policing and } \\
\text { Bhabinkamtibmas and the community }\end{array}$ & $\checkmark$ \\
\hline 32 & 22 & increased openness in provide information; & $\checkmark$ \\
\hline 33 & 22 & increased deep togetherness problem solving; and & - \\
\hline 34 & 22 & $\begin{array}{l}\text { increased intensity of cooperation and participation } \\
\text { of stakeholders. }\end{array}$ & $\checkmark$ \\
\hline
\end{tabular}

Source: Perkap Number 3 of 2015, edited by Author

Based on the data on Table 1, it can be seen that the implementation of counseling by Bhabinkamtibmas in preventing the spread of hoaxes in order to create a safe and peaceful election has not been optimal in article number 3 of 2015 because there are still 14 indicators from total 34 that have not been met. 


\section{IMPLEMENTATION OF COUNSELING BASED ON CAMPBELL'S PERFORMANCE THEORY}

To bring up a good implementation of counseling, the author will bridge the discussion by using the theory of performance from Campbell in Jex and Britt (2008: 99). Mastery of tasks as conveyed by Campbell in his performance theory, there are 8 (eight) main components that must be owned by every officer in carrying out his work. The eight components of the performance include observable behaviors carried out by individuals in the work of officers who are relevant to the goals of the organization. Performance or often referred to as performance is the capital of the police organization that must be owned by all members, including Bhabinkamtibmas.

a. Job specific task proficiency is the extent to which an individual can do the main tasks of his job.

b. Non-job specific task proficiency is the degree to which the individual does a number of specific tasks.

c. Written-oral communication task is the extent to which individual skills in writing and communicating.

d. Demonstrating effort is the extent to which individuals show extra effort to carry out their tasks consistently.

e. Maintaining personal discipline is an individual's effort not to do negative things at work.

f. Facilitating peer and team performance.

g. Supervision is the ability to influence colleagues or subordinates to improve performance through interpersonal interactions.

h. Management administration

Table 2. Conclusions Counseling Based on Performance Theory

\begin{tabular}{cccc}
\hline No & Indicator & Not Fulfilled & Fulfilled \\
\hline 1 & Job specific task proficiency & $\checkmark$ & \\
\hline 2 & Non-job specific task proficiency & & $\checkmark$ \\
\hline 3 & Written-oral communication task & $\checkmark$ & \\
\hline 4 & Demonstrating effort & $\checkmark$ & $\checkmark$ \\
\hline 5 & Maintaining personal discipline & & $\checkmark$ \\
\hline 6 & Facilitating peer and team performance & & $\checkmark$ \\
\hline 7 & Supervision & & $\checkmark$ \\
\hline 8 & Management administration & & \\
\hline
\end{tabular}

The implementation of counseling by Bhabinkamtibmas in preventing the spread of hoax was analyzed according to the Binluh management concept based on articles 8, 9, 10, and 11 of Police Chief Regulation number 21 of 2007 as well as articles 19, 20, 21, and 22 of Police Chief Regulation number 3 of 2015 there were still deficiencies, namely the absence of the readiness of Bhabinkamtibmas officers in 
conducting counseling related to the spread of hoaxes before the election, is not yet optimal in controlling the audience, and the lack of coordination of Bhabinkamtibmas with stakeholders, and figures resulting in the community being less able to analyze the spread of hoax news ahead of the election.

The implementation of counseling by Bhabinkamtibmas is closely related to the task of partnership and problem solving. So that the task of counseling Bhabinkamtibmas is more optimal then it is discussed based on Campbell's Performance theory. Based on Campbell's performance component, it was found that members of Bhabinkamtibmas were still not fulfilled in terms of Job Specific task proficiency, Written-oral communication task, and Demonstrating effort.

\section{FACTORS THAT INFLUENCE EXTENSION BY BHABINKAMTIBMAS}

According to Soekanto (2014: 7). Law enforcement is not merely the implementation of legislation. Despite the reality in Indonesia the tendency is this, so that the notion of law enforcement is so popular. In addition, there is a strong tendency to interpret law enforcement as implementing judges' decisions. It should be noted, however, that these rather narrow opinions have weaknesses. If the implementation of the law or the judges' decisions in fact disturbs peace in the association of life.

In fact, the law upheld in Indonesia is still widely violated, especially the rise of hoaxes circulating at Kebumen Police Station. Based on this Soekanto (2014: 8) argues that the main problem of law enforcement lies in the factors that influence it. These factors are neutral, so they have positive and negative impacts. These factors are:

a. The legal factor itself

b. Law enforcement factors, namely those who form and apply the law

c. Factors of facilities or facilities that support law enforcement

d. Community factors, namely the environment in which the law applies or is applied

e. Cultural Factors, namely as the work, creation and taste based on human initiative in the association of life

The following will be analyzed factors of law enforcement in counseling against the prevention of the spread of hoax by Bhabikamtibas at Kebumen Police Station.

\section{LEGAL FACTOR}

In this study, what is meant by legal factors to ensnare hoaxes is to use Article 28 paragraph 1 of the ITE Law, Articles 14 and 15 of Law number 1 of 1946 of the Criminal Code. The explanation will be described one by one as follows: 
Article 28 paragraph 1 of the ITE Law has not been able to formulate precisely the meaning of hoaxes and it is difficult to capture hoaxes with that article. The reason is that the element "that causes consumer harm" is an element that has material offenses. This means that consumer losses in electronic transactions are prohibited from intentionally and without the right to spread false and misleading news, so there must be material losses such as online fraud that results in financial losses. In the three cases of hoaxes that occurred in Kebumen Police Station although not reported to the level of Investigation but based on the news and the results of the interview. that the three hoax cases were both Terrorist DPO, 8.2 SR Quake and Tsunami, and Video about Fish Flooding in Wadas Lintang Kebumen Reservoir, not a single case of hoaxes can be snared with this article.

Explanation of article 14 paragraph 2 of Law number 1 of 1946 concerning the Criminal Code is more relevant to ensnare the perpetrators of hoax spreaders. Based on all cases of hoaxes that occurred in the Kebumen police area, all elements in article 14 paragraph 2 of the Criminal Code of 1946 can be fulfilled as a result of false news in accordance with article 14 paragraph 2 of the Criminal Code of 1946 namely "causing disturbance in society" is a formal offense that can fulfilled only due to public unrest due to hoaxes circulating in the community. From the above statement it can be concluded that the handling of hoaxes by law enforcement still faces difficulties because there is no article that clearly defines this hoax problem.

From the explanation above it can be seen that there is no concrete legal formulation to ensnare the perpetrators of hoax spreaders. This will result in inhibition of counseling conducted related to hoax prevention because Bhabinkamtibmas cannot inform the public about the effects of jerah to people who do the hoax besides there is no training to Bhabinkamtibmas related to hoax knowledge. This is very worrying because the Kebumen people generally do not have a high level of education so that knowledge about hoaxes is still lacking and prone to Kebumen people easily believe in hoax news. Hoax is mostly done through social media, so that in the ITE Law there must be an update to the legal formulation for hoaxes.

\section{LAW ENFORCEMENT FACTOR}

Human resources have an important influence in supporting the success of an effort to prevent the spread of hoaxes. To provide a quality counseling requires skilled human resources, able to communicate well, fully understand that in this context, especially about preventing the spread of hoaxes, and being able to master the audience.

Personnel factor is one of the factors that influence the delivery of hoax prevention messages. Analysis of the quantity and quality factors of personnel. The quantity of personnel is the strength or the real number of Bhabinkamtibmas Kebumen police personnel, while the quality of personnel is the ability possessed by each Bhabinkamtibmas member in carrying out counseling in preventing the spread of hoaxes. 
Judging from the total number of Bhabinkamtibmas as a whole, there are 95 members, that number is still far from the number of villages and villages in Kebumen Police Station, which are 11 villages and 449 villages. This is why the 1 village 1 Bhabinkamtibmas program is not yet running, there are still many Bhabinkamtibmas that have more than one target village.

The next personnel issue is about the quality of personnel, especially Bhabinkamtibmas at Kebumen Police Station. It can be seen from Bhabinkamtibmas general education that there are 26 personnel who have obtained a bachelor's degree (S1) while there are still 69 personnel who have only graduated from high school. This indicates that members are not interested in improving the quality of their education.

Another factor is also due to the ability of Bhabinkamtibmas to use information and communication technology and the lack of multimedia capabilities possessed by Bhabinkamtibmas. This is evidenced by the lack of counseling through the WA application that uses picture or video messages.

\section{LAW ENFORCEMENT FACILITIES FACTOR}

Supporting facilities or facilities include budget support, facilities and infrastructure as well as the methods used. Budget support is a factor that plays an important role in the implementation of a police activity. An activity will run well if the needs can be met by the available budget.

Even though the budget is still lacking, according to Kasat Binmas this does not matter because Bhabinkamtibmas also has the support of the surrounding community in carrying out its extension work. Then the facility and infrastructure factor in counseling, Bhabinkamtibas does not fully have the equipment that must be owned by a Bhabinkamtibmas in carrying out its duties, in accordance with article 30 of the National Police Chief Regulation number 3 of 2015

\section{COMMUNITY FACTOR}

In implementing counseling by Bhabinkamtibmas to prevent hoaxes must know the intended target. In this study the target is society because of factors within the community that will affect the implementation of counseling. People prefer to make a decision that minimizes their cognitive effort and maximizes confidence (Chen et al., 1999). Dismissing an issue without serious consideration can be a result of reasoning to avoid wasting cognitive effort and minimizing cognitive dissonance. Past research argues that individuals process new information when they have a minimal level of resources to be interested in, such as knowledge (Petty and Cacioppo, 1986), attitude (Krishna, 2017), and ability (Chaiken, 1980).

In terms of Kebumen community education is still relatively low, only $2.3 \%$ of the people who have obtained a bachelor's degree (Sl). This can result in low media literacy capabilities and can easily be provoked and help spread hoaxes. Then the lack of knowledge of the Kebumen community about hoaxes, so prone to become victims of hoax news. 
Low level of education is not really a problem because the willingness to know about hoaxes is quite high. Based on the author's observations during the FGD activities during the study, it was seen that Kebumen people who were FGD participants seemed very enthusiastic about the hoax material presented by the speakers, this was evident from the many FGD participants who wanted to ask questions. Therefore, community enthusiasm can be a supporting factor in the counseling of Bhabinkamtibmas in preventing the spread of hoaxes at Kebumen Police Station.

\section{CULTURAL FACTOR}

The culture that exists in a community sphere is very influential with the law enforcement applied in that society. The social conditions in the Kebumen police station greatly influenced the spread of hoaxes in the Kebumen region. In the Kebumen region, the use of mobile phones is evenly distributed in all circles plus a low level of education further increases the likelihood of spreading hoaxes in Kebumen plus the Indonesian culture that is easy to believe in 'he said'.

The factors that influence the implementation of counseling by Bhabinkamtibmas in preventing the spread of hoax are analyzed using law enforcement theory, with the results of the analysis as follows: Supporting factors are legal factors, facilities/community factors, and community factors, as follows article 28 paragraph 1 of ITE Law and article 14, 15 Law number 1 of 1946 became the basis in ensnaring perpetrators of hoax spreaders, budget and facilities support, as well as public enthusiasm to understand about hoaxes. However, there are deficiencies in defining the effect of hoaxes on legislation which makes it difficult for law enforcers to ensnare hoaxers, the number of Bhabinkamtibmas which is still lacking so that the Bhabinkamtibmas program has not been fulfilled, the lack of Bhabinkamtibmas knowledge about hoaxes, and the consumptive culture of Kebumen and easy to believe in the culture 'he said'. Therefore, based on law enforcement theory, the inhibiting factors are legal factors (legal formulation), law enforcement factors and cultural factors

\section{CONCLUSION}

The results of the study found that there have been three cases of hoaxes in the Kebumen police area. The implementation of counseling by Bhabinkamtibmas in preventing the spread of hoaxes was not optimal because there were still shortages at each stage of the activity and there were still deficiencies in terms of Bhabinkamtibmas officers' knowledge about hoaxes, the ability to establish partnerships, and communication skills. The inhibiting factors are legal factors (legal formulation), law enforcement factors, and cultural factors, while supporting factors are legal factors (foundation), facility / facility factors, and community factors. Based on the results of the study, the authors suggest firmness to ensnare the hoax case, 
coordinate with the cyber patrol task force, prioritize counseling to the grassroots, create a WA group containing all stakeholders, public lectures on hoaxes, mandatory base on Binmas, rejuvenation of Bhabinkamtibmas, appoint Tomas as the 'representative' 'Bhabinkamtibmas, increasing innovation in creative activities, optimizing sarpras, and holding a Da'i Kamtibmas competition.

\section{REFERENCES}

APJII. (2017). Hasil Survei Penetrasi dan Perilaku Pengguna Internet Indonesia 2017, retrieved from https://apjii.or.id/content/read/39/342/Hasil-Survei-Penetrasi-danPerilaku-Pengguna-Internet-Indonesia-2017

Chaiken, S. (1980). Heuristic versus systematic information processing and the use of source versus message cues in persuasion. Journal of Personality and Social Psychology, $39(5), 752-766$.

Chen, S., Duckworthm K., \& Chaike, S. (1999). Motivated heuristic and systematic processing. Psychological Unquiry, 10(1), 44-49.

Gilligan, J.T., \& Gologorsky, Y. (2019). Fake News: Scientific Research in the Age of Misinformation. Journal of World Neurosurgery, 131(284), 284-298. https://doi.org/10/1016/j.wneu.2019.08.083.

Hara, N., \& Sanfilippo, M. R. (2016). Co-construction controversy: Content analysis of collaborative knowledge negotiation on online communities. Information, Cmmunication e Society, 19(11), 1587-1604.

Hanifar, I. (2020). Upaya Satuan Binmas Untuk Menciptakan Suasana Kondusif Menjelang Pilpres 2019 Di Wilayah Hukum Polres Banyumas. Advances in Police Science Research Journal,4(1), 91-142. Retrieved from http://journal.akpol.ac.id/index.php/apsrj/article/view/117

Haqqani, M. I. (2020). Pemanfaatan Media Sosial Instagram Oleh Bhabinkamtibmas Guna Mengantisipasi Penyebaran Hoax Pemilu 2019 di Polres Banyumas. Police Studies Review, 4(1), 297-372. Retrieved from http://journal.akpol.ac.id/index.php/psr/article/view/87

Humberto, M. (2010). Pokdarkamtibmas Pamulang sebagai Implementasi Kemitraan dalam Konteks Community Policing. Jurnal Kriminologi Indonesia, 7(1), 46-66. http://journal.ui.ac.id/index.php/jki/article/viewFile/1094/1006

Indonesian National Police. (2007). Regulation of the Head of the Republic of Indonesia National Police Number 21 Year 2007 regarding Guidance for Guidance on Security and Public Order. (Peraturan Kepala Kepolisian Negara Republik Indonesia Nomor 21 Tahun 2007 tentang Bimbingan Penyuluhan Keamanan dan Ketertiban Masyarakat).

Indonesian National Police. (2015). Regulation of the Head of the Indonesian National Police Number 3 of 2015 concerning Community Policing. (Peraturan Kepala Kepolisian Negara Republik Indonesia Nomor 3 tahun 2015 tentang Pemolisian Masyarakat). Iriantara, Y. (2009). Literasi media Apa, Mengapa dan Bagaimana. Bandung: Refika Aditama. 
Jang, S. M., McKeever, B., McKeever, R., \& Kkim, J. K. (2017). From social media to mainstream news: The information flow of the vaccine-autism controversy in the US, Canada, and the UK. Health Communication, 34(1), 110-117. https://doi.org/10.1080/10410236 (in press)

Jex, S. M., \& Britt, T. W. 2008. Organizational Psychology A Scientist-Practitioner Approach. New Jersey: John Wiley \& Sons, Inc.

Krishna, A. (2017). Motivation with misinformation: Conceptualizing lacuna individuals and publics as knowledge-deficient, issue-negative activists. Journal of Public Relations Research, 29(4), 176-193.

Lazer, D., Baum, M., Grinberg, N., Friedland, L., Joseph, K., Hobbs, W., et al. (2017). Combating fake news: An Agenda for research and action. Retrieved from https://shorensteincenter.org/combating-fake-news-agenda-for-research/.

Mauludi, S. (2018). Bijak, Kritis \& Inspiratif Seputar Dunia \& Masyarakat Digital. Jakarta: PT. Gramedia.

Moleong, L.J. (2017). Metodologi Penelitian Kualitatif. Bandung: PT. Remaja Rosdakarya.

Moleong, L.J. (2014). Metodologi Penelitian Kualitatif. Bandung: PT. Remaja Rosdakarya.

Nainggolan, D. J. M. (2020). Penggalangan Intelijen dalam Pencegahan Penyebaran Hoax Menjelang Masa Pemilihan Presiden di Wilayah Hukum Polres Salatiga. Indonesian Journal of Police Studies,4(1), 67-106. Retrieved from http://journal.akpol.ac.id/index.php/ijps/article/view/75

Nugroho, A.R. (2018). Peran Bhabinkamtibmas Dalam Pencegahan Konflik Sosial Berbasis Agama di Polresta Bogor Kota. Thesis. Semarang: Akademi Kepolisian.

Pamungkas, A.D., \& Arifin, R. (2019). Demokrasi dan Kampanye Hitam dalam Penyelenggaraan Pemilihan Umum di Indonesia (Analisis atas Black Campaign dan Negative Campaign). DIKTUM: Jurnal Syariah dan Hukum 17(1), 16-30. DOI: https://doi.org/10.35905/diktum.vl7il.641

Park, Y. J. (2017). Social antecedents and consequences of political privacy. New media \& Society, 20(7), 2352-2369. https://doi.org/10.1077/1461444817716677.

Parkinson, H. J. (2016). Click and Elect: How fake news helped Donal Trump win a real election. The Guardian. Retrieved from https://www.theguardian.com/commentisfree/2016/nov/14/fake-news-donaldtrump-election-alt-right-social-media-tech-companies

Petty, R. E., \& Cacioppo, J. T. (1986). The elaboration likelihood model of persuasion. Advances in experimental social psychology, 19(1), 123-205.

Prabawa, A. N. M. P. (2017). Optimalisasi Peran Bhabinkamtibmas dalam Penanggulangan Kelompok Radikal di Polres Brebes: Optimization of the Role of Bhabinkamtibmas in Prevention of Radical Groups in Brebes Police. Indonesian Journal of Police Studies, 1(1), 1-82. Retrieved from http://journal.akpol.ac.id/index.php/ijps/article/view/1

Prastowo, A. (2011). Metode Penelitian Kualitatif dalam Perspektif Rancangan Penelitian. Jakarta: Ar-Ruzz Media. 
Prasetia, A. (2018). Marak Isu Hoax, Jokowi: Saya Perintahkan Kapolri Tindak Tegas. Detik News, retrieved from https://news.detik.com/berita/d-3900859/marak-isuhoax-jokowi-saya-perintahkan-kapolri-tindak-tegas

Pranesti, D.A., \& Arifin, R. (2019). Perlindungan Korban dalam Kasus Penyebaran Berita Hoax di Media Sosial di Indonesia. Jurnal Hukum Media Bhakti 3(1), 8-17. DOI: https://doi.org/10.32501/jhmb.v3il.35

Rahadi, D.R. (2017). Perilaku Pengguna dan Informasi Hoax di Media Sosial. Jurnal Manajemen dan Kewirausahaan, 5(1), 58-70.

Ramadhan, W. (2020). Upaya Penyuluhan oleh Satuan Binmas dalam Mencegah Penyebaran Berita Hoaks Melalui Media Sosial di Wilayah Hukum Polres Banyumas Guna Menciptakan Kamtibmas Menjelang Pemilu 2019. Police Studies Review, 4(1), 121-184. Retrieved from http://journal.akpol.ac.id/index.php/psr/article/view/84

Read, M. (2016). Donald Trump won because of facebook. New York Intelligencer. Retrieved from https://nymag.com/intelligencer/2016/11/donald-trump-wonbecause-of-facebook.html

Republic of Indonesia. (1946) Law Number 1 of 1946 concerning Criminal Law Regulations. (Undang-undang Nomor 1 Tahun 1946 tentang Peraturan Hukum Pidana).

Republic of Indonesia. (2016). Law Number 19 of 2016 concerning Electronic Information and Transactions. (Undang-undang Nomor 19 Tahun 2016 tentang Informasi dan Transaksi Elektronik 'ITE').

Ridho, M. (2018). Penjelasan Polres Kebumen tentang Teroris Cantik. Online News Liputan 6, retrieved from https://www.liputan6.com/regional/read/3621215/penjelasan-polres-kebumententang-teroris-cantik

Safitri, E., \& A Andayani, D. (2019). Geger Hoax 7 Kontainer Surat Suara Tercoblos. Detik News, retrieved from https://news.detik.com/berita/4370218/geger-hoax-7kontainer-surat-suara-tercoblos

Soekanto, S. (2014). Faktor-faktor yang mempengaruhi Penegakan Hukum. Jakarta: PT. Raja Grafindo Persada.

Spence, P. R., Lachlan, K.A., Edwards, A., \& Edwards, C. (2016). Tweeting fast matters, but only if I think about it: Information updates on social media. Communication Quarterly, 64(1), 55-71.

Sudrajat,, Y. (2019). Mewujudkan Pemilu 2019 yang Berkualitas dan Berintegritas Serta Bebas Dari Hoax. Unpublished Paper, presented at the Police Academy School Seminar, Semarang, 6 February 2019.

Tambuscio, M., Ruffo, G., Flammini, A., \& Menczer, F. (2015, May). Fact-checking effent on viral hoaxes: A model of misinformation spread in social networks. Proceedings of the $24^{\text {th }}$ international conference on World Wide Web (pp.977-982) ACM.

Zulkarnaen, A. (2018). Optimalisasi Penyuluhan Dalam Pencegahan Penyebaran Hoax (Studi Pemanfaatan Media Sosial WhatssApp oleh Bhabinkamtibmas di Polres Cimahi). Thesis. Semarang: Akademi Kepolisian. 